\title{
Endocrinology, Legal Liability and Sub-Specialisation
}

\author{
George Gregory Buttigieg* and Kirill Micallef Stafrace \\ University of Malta, Malta
}

*Corresponding author: George Gregory Buttigieg, University of Malta, Malta

Submission: February 24, 2018; Published: 㭗February 26, 2018

\section{Editorial}

In a world of meteorically expanding medical knowledge, specialisation, sub-specialisation and super sub-specialisation are normal terms of the day, in civilised countries where infrastructure and population numbers demographically and financially uphold such medical sub-divisions. Once such labels attain official recognition along with the blessing of the medical council, medical registration or equivalent, the ensuing rights and duties become enshrined at law. Endocrinology is one such recognised subdivision of Medicine, indeed a major sub-division, which has long been in existence and more than justifiably established itself.

Yet, endocrinological management overlaps a number of other medical sub-divisions such as diabetology and also spills over onto other major fields such as gynaecology. This leads to inevitable questions of daily significance and colossal practical importance, especially if matters reach jurisprudential evaluation. When should a gynaecologist bow out and hand over to an endocrinologist and what liability is incurred if he does not or does not do so, in due time? The answers to these questions can only be answered with regard to evaluation of specific cases and, in addition, will vary from from country to country, from time to time, from jurisdiction to jurisdiction and finally, also be dictated by the clinical outcome.

Such theorising may not be as far-fetched as one may imagine. In Clarke v General Optical Council [1], we find that a British optometrist ignored signs that should have alerted him to refer to family doctor, in the first instance, and which were, in fact, a manifestation of a pituitary tumour which led to blindness. Admittedly, not an endocrinological case this serves to make a point about referral. And, closely, enough, how often are, eventually significant pituitary tumours, hidden beneath the "hyper-prolactinaemia", discovered, say, during an infertility related hormone investigation? Even the very treatment of hyper-prolactinaemia, in the light of new jurisprudential guidance on disclosure of information, may lead to serious liability. As we speak, one local obstetrician faces liability charges in Court by failing to disclose sufficient information to a pregnant woman who stopped her dopamine for hyperprolactinaemia in pregnancy, subsequently suffering limited visual field loss.

Our advice is for prudence to guide management. Keeping to the argument of the gynaecologist and the endocrinologist. If the former is not happy to completely refer (and lose contact with) a particular patient, prudence advices, joint endocrinological management. Unfortunately, familiarity does breed contempt. Unless the gynaecologist is a true endocrinological gynaecologist, he may hardly be fully au fait with the latest advances, say, on the pituitary-specific transcription factor-1 regulating the expression and differentiation of human growth hormone, prolactin and TSH, and the mechanism of regulation of somatotrophs' apoptosis via Ret receptors. Even if he is, referring the patient for an endocrinological opinion, if coupled with a genuine explanation, increases the rapport and humanity with the patient, who always admires the doctor who seeks advice from other experts, for better management.

In our opinion, the traditional, one size fits all, of a specialist who knows it all, has long since expired. It is unfair to the speciality, to the patient and to the specialist himself. This is crucial in countries like Malta, where excellent European level medicine is practised, but, where, pure sub-specialist practice is dogged by the sheer size limitation of a total population of 422,411 souls. In such a limited population, the very nature of sub-specialisation incurs an inherent challenge of existence, which, leads to a theoretical sub-specialist who reverts to generalisation in actual practice. Even so, and especially in such an environment as the present one in the Island of Malta, on medico-legal grounds, we recommend joint management and practice review on even firmer grounds than elsewhere. For the rapidly and increasingly heterogeneous population, poses new medical challenges of diagnosis and management, both from the increasingly foreign 'European' component, but even more so from irregular immigration [2]. Non-local European patients not only have recourse to local Courts, but, naturally, as a last resort, also to the European Courts. Irregular migrants also have recourse to the Courts of Human Rights, whatever their official immigrant status of recognition.

The subject of consciousness of legal liability has dominated this Editorial. In a world, increasingly dominated by medico-legal challenge, this hardly demands an apology. Yet, on deep reflection, 
our best management practice should be motivated, by the most appealing of all calls. The duty to do right by our patients.

\section{References}

1. Christopher P (2017) Clarke v General Optical Council EWHC 521 (Admin).

For possible submissions Click Here
2. Buttigieg GG (2017) Obstetric and medico-legal challenges posed by sudden immigrant shift in a southern mediterranean island. Anthropol 5(3): e. 1000185.

Your subsequent submission with Crimson Publishers will attain the below benefits

- High-level peer review and editorial services

- Freely accessible online immediately upon publication

- Authors retain the copyright to their work

- Licensing it under a Creative Commons license

- Visibility through different online platforms

- Global attainment for your research

- Article availability in different formats (Pdf, E-pub, Full Text)

- Endless customer service

- Reasonable Membership services

- Reprints availability upon request

- One step article tracking system 